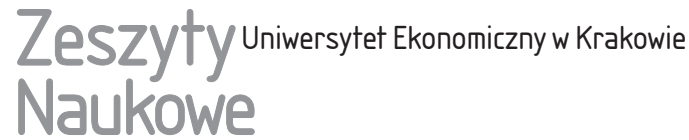

\section{Polityka zrównoważonego rozwoju gmin śląskich}

\section{Streszczenie}

Samorządy lokalne, po rozwiązaniu w pierwszym okresie po odrodzeniu samorządności bieżących problemów, zaczęły odczuwać potrzebę wypracowania kompleksowej wizji rozwoju. Jedną z możliwości konstruowania nowoczesnych strategii rozwoju jest kierowanie się wskazówkami formułowanymi w ramach koncepcji zrównoważonego rozwoju. Praktyczna implementacja polityki opartej na zasadach zrównoważonego rozwoju wymaga istnienia woli politycznej i przychylności władz samorządowych dotyczącej wdrażania rozwiązań zgodnych z tą koncepcją. Celem artykułu jest ocena postępów wdrażania polityki opartej na zasadach zrównoważonego rozwoju w gminach województwa śląskiego. Podstawową metodą badawczą jest analiza danych zawartych w ankiecie na temat polityki zrównoważonego rozwoju, przeprowadzonej przez pracowników Katedry Polityki Społecznej i Gospodarczej Uniwersytetu Ekonomicznego w Katowicach w 2015 r. Analizując uzyskane wyniki, odwołano się również do wcześniej przeprowadzonych badań ankietowych. Na podstawie przeprowadzonych badań można stwierdzić, że istnieje postęp we wprowadzaniu zasad zrównoważonego rozwoju w polityce lokalnej, lecz jest on bardzo wolny. Pierwsze badania przeprowadzane w gminach na początku transformacji systemowej wskazywały na ok. 5-procentowy udział samorządów próbujących wdrażać politykę zrównoważonego rozwoju w gminie, a obecnie udział ten wynosi ok. $25 \%$ badanych gmin.

Słowa kluczowe: zrównoważony rozwój, polityka, samorządy terytorialne, województwo śląskie.

Klasyfikacja JEL: Q01.

Agnieszka Lorek, Uniwersytet Ekonomiczny w Katowicach, Wydział Ekonomii, Katedra Polityki Społecznej i Gospodarczej, ul. 1 Maja 50,40-287 Katowice, e-mail: agnieszka.lorek@ue.katowice.pl 


\section{Wprowadzenie}

Podstawowym celem polityki z punktu widzenia społeczeństwa powinien być wzrost jego dobrobytu lub osiągnięcie określonego jego poziomu (jeżeli traktować problem w ujęciu zrównoważonego rozwoju). Na dobrobyt składa się w zasadzie pięć czynników wzajemnie ze sobą powiązanych, którymi są: poziom dochodu, dystrybucja dochodu między różne grupy społeczne, dystrybucja dochodu w czasie (podział konsumpcja-inwestycje), struktura zatrudnienia (w szczególności poziom bezrobocia) oraz stan środowiska naturalnego. Celem działania polityków jest utrzymanie władzy, a niekoniecznie realizowanie określonych celów społecznych, natomiast potrzeba poddawania się weryfikacji społecznej w procedurach demokratycznych skłania polityków, aby realizować swoje cele indywidualne przez realizację celów społecznych. Dlatego też polityka jest sferą silnie zależną od świadomości i wiedzy społeczeństwa oraz polityków. Kierunki oraz sposoby kreowania rozwoju lokalnego również uzależnione są przede wszystkim od polityki, a szczególnie poglądów i postaw ludzi, w tym polityków, którzy mają na nie wpływ. Ważna jest więc diagnoza kondycji społeczeństwa obywatelskiego jako istotnego, a często ignorowanego czynnika zrównoważonego rozwoju. Samorządy lokalne, po rozwiązaniu w pierwszym okresie po odrodzeniu samorządności bieżących problemów, zaczęły odczuwać potrzebę wypracowania kompleksowej, wybiegającej w przyszłość wizji rozwoju społecznego, gospodarczego i przestrzennego. Jedną z możliwości konstruowania nowoczesnych, prorozwojowych strategii rozwoju i programów politycznych zapewniających funkcjonowanie społeczeństwa w stabilnym otoczeniu oraz niwelowanie głównych zagrożeń związanych z rozwojem cywilizacji (np. zanieczyszczeniem środowiska) jest kierowanie się wskazówkami formułowanymi w ramach koncepcji zrównoważonego rozwoju.

Celem badawczym niniejszego artykułu jest ocena postępów wdrażania polityki opartej na zasadach zrównoważonego rozwoju w gminach województwa śląskiego. Podstawową metodą badawczą zastosowaną w artykule jest analiza danych zawartych w ankiecie na temat polityki zrównoważonego rozwoju. Badania ankietowe przeprowadzone zostały w ramach badań statutowych Katedry Polityki Społecznej i Gospodarczej Uniwersytetu Ekonomicznego w Katowicach w gminach województwa śląskiego, podlaskiego oraz wielkopolskiego w 2015 r. Ankieta skierowana była do wszystkich gmin wymienionych województw, lecz w poniższym artykule wykorzystano dane dotyczące województwa śląskiego, dla którego uzyskano zwrot na poziomie $64,7 \%$ ogółu gmin województwa. Uzyskane wyniki ankiety uzupełniono analizą wcześniej przeprowadzonych badań ankietowych w gminach województwa śląskiego, takich jak badania na temat stanu wdrożenia Lokalnej Agendy 21 przeprowadzone w 2000 r. przez Polski Klub Ekologiczny w Gliwicach oraz Szwedzko-Polskie Towarzystwo Ochrony Środowiska 
w Sztokholmie oraz badania dotyczące programowania zrównoważonego rozwoju na poziomie lokalnym prowadzone przez Katedrę Zarządzania Ochroną Środowiska Uniwersytetu Ekonomicznego w Katowicach pod kierownictwem prof. dr hab. Elżbiety Lorek w latach 2002 i 2010.

\section{Polityka zrównoważonego rozwoju: ujęcie historyczno- -teoretyczne}

Idea realizacji rozwoju społeczno-gospodarczego zharmonizowanego z przyrodą pojawiła się na początku lat 70. na sesjach Rady Zarządzającej Programu Środowiskowego Narodów Zjednoczonych - II sesji w Sztokholmie w 1972 r. i III sesji w Nairobi w 1975 r. Pierwsza zasada deklaracji sztokholmskiej mówi, że człowiek ma niepodważalne prawo do wolności, równości i odpowiednich warunków życia w środowisku, które pozwala mu zachować godność i żyć w dobrobycie [Międzynarodowe prawo... 2009, s. 53-58]. W 1975 r. sformułowano pojęcie społeczeństwa ekorozwoju jako społeczeństwa uznającego nadrzędność wymogów ekologicznych, które nie mogą być zakłócane przez wzrost cywilizacji oraz rozwój kulturowy i gospodarczy. Respektowany powinien być wymóg oszczędnej produkcji i konsumpcji oraz wtórnego wykorzystania odpadów [United Nations Environment... 1975]. Sens i znaczenie temu pojęciu nadał raport Światowej Komisji ds. Środowiska i Rozwoju zatwierdzony przez Organizację Narodów Zjednoczonych w 1987 r. pt. Nasza wspólna przyszłość [Report of the World... 1987]. Przyjęto, że trwały i sprawiedliwy rozwój oznacza:

1) trwałość ekologiczną,

2) rozwój ekonomiczny,

3) sprawiedliwość społeczną między pokoleniami i w obrębie każdego pokolenia.

Zgodnie z wspomnianym raportem trwałość wzrostu oznacza, że potrzeby teraźniejsze nie są zaspokajane kosztem zmniejszenia możliwości przyszłych pokoleń do zaspokojenia swoich potrzeb. Trwałość i samopodtrzymywanie się wzrostu implikuje zatem nie tylko krótkookresową, ale również międzygeneracyjną sprawiedliwość. W raporcie środowisko i rozwój traktuje się nierozdzielnie, wychodząc z założenia, że spirala ubóstwa i nierówności społecznych oraz degradacji środowiska oznacza straty możliwości i zasobów rozwojowych. Uznano wtedy, że dla realizacji koncepcji trwałego rozwoju konieczne jest określenie polityki środowiskowej i gospodarczej, czyli ożywienie wzrostu gospodarczego, zaspokojenie podstawowych potrzeb ludzkości w zakresie pracy, wyżywienia, energii i higieny, stabilizacja liczby ludności, zachowanie bogactw naturalnych, zmiana modeli zarządzania oraz profilu technologii na przyjazne środowisku. Obok ochrony zasobów naturalnych za istotne uznaje się zaspokojenie podstawo- 
wych potrzeb ludzi i likwidacji ubóstwa oraz wielopokoleniowej promocji rozwoju. Odpowiedzialność za stworzenie warunków do realizacji działań zgodnych z zasadami trwałego rozwoju ponosić mają przede wszystkim rządy państw na podstawie strategii, planów i programów formułowanych we współpracy z szerokimi kręgami społecznymi i organizacjami pozarządowymi.

Koncepcję trwałego rozwoju rozwinięto i doprecyzowano na Konferencji Organizacji Narodów Zjednoczonych „Środowisko i Rozwój” w Rio de Janeiro. W czasie konferencji przyjęto szereg dokumentów o charakterze prawa międzynarodowego, w których zawarto istotę zrównoważonego rozwoju. Wyznaczają one kierunki dalszego rozwoju ludzkości w skali Ziemi, regionów i państw oraz strategię przeciwdziałania negatywnym zmianom globalnym (zanik różnorodności biologicznej, zmiany klimatu, wylesianie). Najważniejszym aktem podsumowującym Szczyt Ziemi w Rio de Janeiro była Agenda 21 - zbiór wytycznych dla kręgów biznesu i rządów dotyczących prowadzonej przez nie polityki [Dokumenty końcowe Konferencji... 1998]. Agenda 21 wskazuje, w jaki sposób rozwój może zostać zrównoważony w kategoriach gospodarczych, społecznych i ekologicznych. Zgodnie z nią, by móc się rozwijać w sposób zrównoważony, kraje powinny znaleźć sposoby osiągania rozwoju gospodarczego przy jednoczesnym obniżeniu zużycia energii i materiałów oraz zmniejszeniu ilości powstających odpadów, a także określić ogólnoświatowe modele konsumpcji pozwalające zachować bogactwo środowiska przez długi okres. Agenda 21 powierza władzom lokalnym ważną rolę w praktycznym wprowadzaniu zaleceń i działań określonych w tym dokumencie. Według zapisów w niej zawartych rola władz lokalnych w kreowaniu rozwoju jest bardzo istotna, gdyż to właśnie one tworzą i utrzymują infrastrukturę techniczną i społeczną, realizują zadania związane z zagospodarowaniem przestrzennym, utrzymaniem czystości i porządku oraz realizują krajową i regionalną politykę ekologiczną. Ponadto władze lokalne mają do spełnienia misję propagatora zasad zrównoważonego rozwoju w społecznościach lokalnych. Władze lokalne mają za zadanie podjąć i prowadzić dialog ze społeczeństwem, zainicjować konsultacje służące rozwijaniu współpracy ze wszystkimi uczestnikami tego dialogu [Lorek 2003]. Aby zrealizować Lokalną Agendę 21, konieczne jest [Lorek 2011]1:

- zorganizowanie systemu konsultacji z mieszkańcami, organizacjami społecznymi, instytucjami gospodarczymi (łącznie z prywatnymi),

- wypracowanie w drodze takich konsultacji zgody co do podstawowych założeń lokalnej strategii prośrodowiskowej,

- uzyskanie stałego dostępu do informacji umożliwiających bieżącą weryfikację i optymalizację strategii łącznie z uwzględnieniem wymagań wynikających z programów wyższego stopnia,

\footnotetext{
${ }^{1}$ Lokalna Agenda 21 to dokument zawierający strategię wdrażania zrównoważonego rozwoju w gminie.
} 
- wypracowanie systemu zasilania finansowego działań podejmowanych w ramach strategii z wykorzystaniem możliwie najbardziej zróżnicowanych źródeł, w tym zagranicznych,

- kształtowanie i podnoszenie stopnia świadomości ekologicznej społeczeństwa przede wszystkim przez bieżący udział w przygotowaniu i wykorzystaniu strategii.

Współcześnie koncepcja zrównoważonego rozwoju stała się integralną częścią wielu planów i działań państwa zarówno na szczeblu centralnym, jak i w praktyce funkcjonowania samorządów terytorialnych. Próbując zdefiniować współcześnie realizowaną politykę zrównoważonego rozwoju, można stwierdzić, że jest częścią ogólnej polityki państwa, która integruje i harmonizuje politykę społeczną, gospodarczą i ekologiczną. Podstawowym celem tej polityki jest zapewnienie efektywnego funkcjonowania makrosystemu społeczeństwo-gospodarka-środowisko. Polityka zrównoważonego rozwoju nie jest więc tożsama z sektorową polityką ochrony środowiska, lecz polityką społeczno-gospodarczą uwzględniającą realne, występujące obecnie bądź możliwe do przewidzenia, bariery rozwoju wynikające z naturalnej ograniczoności zasobów naturalnych. Należy jednak mieć na uwadze, że nieusuwalne naturalne bariery rozwoju występują w sferze ekologicznej, dlatego polityka zrównoważonego rozwoju koncentrująca się na nich może być czasem postrzegana jako polityka ekologiczna, a nawet jako polityka ochrony środowiska. Kreowanie polityki zrównoważonego rozwoju powinno uwzględniać pewne zasady, do których można zaliczyć [Żylicz 2004, s. 201]:

- powściągliwość (ukształtowanie innych hierarchii wartości i postaw ludzkich),

- prawo jakości ponad ilość (zasobność materialna człowieka),

- cele człowieka zharmonizowane z możliwościami rozwoju przyrody (w skali globalnej i lokalnej),

- efektywne wykorzystywanie nieodnawialnych zasobów przyrody przy zachowaniu zamkniętych cykli,

- ochrona środowiska włączona do ogólnych celów i szczegółowych decyzji polityki państwa,

- procesy decyzyjne (na szczeblu centralnym i lokalnym) z udziałem społecznym,

- konieczność uwzględnienia w rozwoju gospodarczym wymagań i możliwości środowiska przyrodniczego, rozwój ten nie może odbywać się kosztem przyszłych pokoleń,

- stworzenie jednakowych szans życia i rozwoju wszystkich ludzi.

Praktyczna implementacja polityki opartej na zasadach zrównoważonego rozwoju wymaga istnienia woli politycznej i przychylności władz samorządowych dotyczącej wdrażania rozwiązań zgodnych $\mathrm{z}$ tą koncepcją, a podstawowym zadaniem stojącym przed lokalnymi politykami jest wybór priorytetów i kształtowanie kierunków rozwoju odpowiednich dla danej zbiorowości lokalnej. 


\section{Ocena postępów wdrażania polityki zrównoważonego rozwoju w gminach województwa śląskiego}

Po Szczycie Ziemi w Rio de Janeiro opracowywanie Lokalnych Agend 21 było początkowo głównie inicjatywą zewnętrznych organizacji i agencji, a nie samych samorządów. Pierwsze działania w ramach Lokalnej Agendy 21 w Polsce, podobnie zresztą jak na całym świecie, miały charakter programów pilotażowych w wybranych gminach i prowadzone były we współpracy z zewnętrznymi partnerami. Jak ocenia T. Borys [2002], w tym okresie zasady zrównoważonego rozwoju i Agendy 21 były znane władzom lokalnym w nie więcej niż 5\% wszystkich polskich gmin. W zależności od zaawansowania wdrażania zasad Agendy 21 polskie gminy, powiaty i województwa można podzielić na trzy grupy [Borys 2002]:

- grupa I - zasady zrównoważonego rozwoju są nieznane lub są traktowane jako luksus, na który nie stać samorządu. Ochrona środowiska jest traktowana jako bariera rozwoju gospodarczego. Do tej grupy można zaliczyć 60\% gmin i powiatów w Polsce (sytuacja ta dotyczy także województwa śląskiego);

- grupa II - samorząd ogranicza swoje zainteresowanie do spraw ochrony środowiska, czyli do tworzenia „małej” Lokalnej Agendy 21 równoznacznej z lokalną polityką ekologiczną lub jej częścią. Ten sposób rozumienia Agendy 21 w Polsce dominuje;

- grupa III - grupa ta reprezentuje najwyższy poziom wdrażania zasad zrównoważonego rozwoju. Koncepcja zrównoważonego rozwoju jest włączona w cały proces planowania lokalnego i regionalnego (tworzenie ,dużej” Agendy 21). Jej istotą jest partnerstwo międzysektorowe w procesie tworzenia ekorozwoju.

Badania dotyczące stanu wdrożenia Lokalnej Agendy $21 \mathrm{w}$ gminach południowej Polski przeprowadzone zostały w 2000 r. przez Polski Klub Ekologiczny w Gliwicach oraz Szwedzko-Polskie Towarzystwo Ochrony Środowiska w Sztokholmie. Wynika z nich, że tylko niewielka część gmin posiada takie opracowania. Badaniami objęto 283 gminy południowej Polski. Przedstawiciele urzędów ocenili swój poziom wiedzy na temat Agendy 21 oraz przedstawili stopień jej realizacji. W województwie śląskim na pytania zawarte w ankiecie (wysłano 184 ankiety) odpowiedzieli przdstawiciele 81 gmin, z czego Agendę 21 realizowało tylko 19 gmin. Gminy nierealizujące Agendy 21 najczęściej uzasadniały to brakiem informacji, brakiem funduszy oraz brakiem szkoleń [Raport o stanie wdrożenia... 2000]. Późniejsze badania wskazują, że sytuacja w tym zakresie powoli się poprawia. Badania podejmujące powyższą tematykę [Zarządzanie środowiskiem... 2002, Ocena programowania... 2010] zostały przeprowadzone przez Katedrę Zarządzania Ochroną Środowiska Uniwersytetu Ekonomicznego w Katowicach. Większość badanych jednostek wskazało na posiadanie przez gminy opracowanego dokumentu z zakresu zrównoważonego rozwoju i strategii rozwoju (odpowiednio 
61\% i 64\%) [Lorek i Sobol 2012, s. 151-169]. W badaniach przeprowadzonych w 2015 r. w ramach badań statutowych Katedry Polityki Społecznej i Gospodarczej (są one przedmiotem poniższej analizy) posiadanie takiego dokumentu deklarowało 53,3\% gmin. O wyniku zdecydował być może wyższy zwrot kwestionariuszy ankiet (w badaniach z 2010 r. prowadzonych przez Katedrę Zarządzania Ochroną Środowiska Uniwersytetu Ekonomicznego w Katowicach zwrot wynosił 33,5\%, a w 2015 r. wynosił 64,7\%). Jeżeli dokument taki powstawał, zwykle jego tworzenie miało charakter uspołeczniony. Jedynie trzy gminy stwierdziły, że nie prowadziły konsultacji społecznych w tym zakresie. 53\% ankietowanych gmin opracowało również cele zrównoważonego rozwoju. Aby lepiej zobrazować sytuację w zakresie programowania zrównoważonego rozwoju, badane gminy zostały podzielone na trzy grupy o różnym poziomie zaawansowania. Podziału dokonano na podstawie odpowiedzi udzielonych na poniższe pytania:

1) czy gmina posiada strategię rozwoju?

2) czy gmina deklaruje posiadanie dokumentu z zakresu zrównoważonego rozwoju i czy jego tworzenie miało charakter uspołeczniony ${ }^{2}$ ?

3) czy gmina opracowała cele zrównoważonego rozwoju?

4) czy gmina prowadzi monitoring postępów w zakresie zrównoważonego rozwoju?

Tabela 1. Ranking gmin pod względem zaawansowania procesu programowania zrównoważonego rozwoju

\begin{tabular}{|c|c|c|}
\hline Grupa I & Grupa II & Grupa III \\
\hline \multicolumn{3}{|c|}{ Gminy miejskie } \\
\hline $\begin{array}{l}\text { Bytom } \\
\text { Czeladź } \\
\text { Częstochowa } \\
\text { Dąbrowa Górnicza } \\
\text { Gliwice } \\
\text { Kalety } \\
\text { Katowice } \\
\text { Mysłowice } \\
\text { Pszów } \\
\text { Racibórz } \\
\text { Radlin } \\
\text { Ruda Śląska } \\
\text { Rydułtowy } \\
\text { Sławków } \\
\text { Tychy } \\
\text { Żory }\end{array}$ & $\begin{array}{l}\text { Bieruń } \\
\text { Bobrowniki } \\
\text { Chorzów } \\
\text { Jastrzębie Zdrój } \\
\text { Knurów } \\
\text { Lędziny } \\
\text { Lubliniec } \\
\text { Łaziska Górne } \\
\text { Orzesze } \\
\text { Piekary Śląskie } \\
\text { Radzionków } \\
\text { Rybnik } \\
\text { Tarnowskie Góry } \\
\text { Ustroń } \\
\text { Wodzisław Śląski } \\
\text { Żywiec }\end{array}$ & $\begin{array}{l}\text { Będzin } \\
\text { Miasteczko Śląskie } \\
\text { Mikołów } \\
\text { Myszków } \\
\text { Poręba } \\
\text { Szczyrk } \\
\text { Wisła }\end{array}$ \\
\hline
\end{tabular}

${ }^{2}$ Nie zawsze gminy posiadające strategię rozwoju oceniają ją jako zgodną z zasadami zrównoważonego rozwoju. 
cd. tabeli 1

\begin{tabular}{|c|c|c|}
\hline Grupa I & Grupa II & Grupa III \\
\hline \multicolumn{3}{|c|}{ Gminy miejsko-wiejskie } \\
\hline Toszek & $\begin{array}{l}\text { Czechowice-Dziedzice } \\
\text { Czerwionka-Leszczyny } \\
\text { Łazy } \\
\text { Siewierz } \\
\text { Skoczów } \\
\text { Sośnicowice } \\
\text { Wilamowice }\end{array}$ & $\begin{array}{l}\text { Blachownia } \\
\text { Kłobuck } \\
\text { Koniecpol } \\
\text { Pszczyna } \\
\text { Strumień }\end{array}$ \\
\hline \multicolumn{3}{|c|}{ Gminy wiejskie } \\
\hline $\begin{array}{l}\text { Bestwina } \\
\text { Bojszowy } \\
\text { Godów } \\
\text { Gorzyce } \\
\text { Łodygowice } \\
\text { Ornontowice } \\
\text { Pawłowice } \\
\text { Suszec } \\
\text { Wielowieś }\end{array}$ & \begin{tabular}{|l} 
Buczkowice \\
Gaszowice \\
Hażlach \\
Istebna \\
Kamienica Polska \\
Kozy \\
Kroczyce \\
Krupski Młyn \\
Kruszyna \\
Lubomia \\
Miedźna \\
Pilchowice \\
Poczesna \\
Porąbka \\
Starcza \\
Ślemień \\
Świerklany
\end{tabular} & $\begin{array}{l}\text { Czernichów } \\
\text { Gilowice } \\
\text { Goleszów } \\
\text { Imielin } \\
\text { Irządze } \\
\text { Janów } \\
\text { Jasienica } \\
\text { Kłomnice } \\
\text { Kobiór } \\
\text { Krzyżanowice } \\
\text { Lelów } \\
\text { Lipie } \\
\text { Lyski } \\
\text { Łękawica } \\
\text { Miedźno } \\
\text { Mierzęcice } \\
\text { Nędza } \\
\text { Niegowa } \\
\text { Poraj } \\
\text { Przyrów } \\
\text { Przystajń } \\
\text { Radziechowy-Wieprz } \\
\text { Rędziny } \\
\text { Świnna } \\
\text { Włodowice } \\
\text { Wręczyca Wielka } \\
\text { Żarnowiec }\end{array}$ \\
\hline
\end{tabular}

Źródło: opracowanie własne na podstawie wyników badań ankietowych.

W grupie I znalazły się samorządy, które odpowiedziały twierdząco na wszystkie powyższe pytania. Grupa II obejmuje gminy, których przedstawiciele udzielili odpowiedzi twierdzących na niektóre z pytań. Grupę III tworzą samorządy, które nie udzieliły żadnej pozytywnej odpowiedzi, a tym samym nie są zainteresowane prowadzeniem polityki opartej na zasadach zrównoważonego rozwoju. Tabela 1 prezentuje uzyskane wyniki. 
Analizując uzyskane wyniki, można stwierdzić, że w grupie I (24,8\% badanych gmin), posiadającej najpełniej opracowaną dokumentację, dominują największe samorządy (gminy miejskie) mające najlepszy dostęp do zaplecza eksperckiego (wyższe uczelnie, instytuty badawcze, np. Instytut Ekologii Terenów Uprzemysłowionych w Katowicach) i dysponujące odpowiednio wykształconą kadrą urzędniczą. Grupa III $(37,1 \%)$ to zaś przede wszystkim małe gminy wiejskie. Nie wyklucza to oczywiście możliwości tworzenia odpowiednich dokumentów strategicznych przez gminy wiejskie, czego przykładem jest zaliczenie niektórych z nich do grupy I. W małej gminie kluczowym czynnikiem decydującym o możliwości tworzenia dokumentów strategicznych wysokiej jakości jest zatrudnienie osoby o odpowiednich kompetencjach, która będzie potrafiła koordynować i poprowadzić prace.

Grupa II $(38,1 \%)$ jest bardziej zróżnicowana. Są to gminy, które mają opracowane pewne elementy programowania zrównoważonego rozwoju przejawiające się posiadaniem dokumentu w tym zakresie lub zainicjowaniem procesu monitorowania postępów wdrażania zrównoważonego rozwoju (co ciekawe niektóre samorządy nie posiadały dokumentów strategicznych, ale deklarowały prowadzenie monitoringu). Dane zawarte w ankietach tej grupy wskazują jednak na braki i niedoskonałości występujące w dokumentacji. Do najważniejszych problemów można zaliczyć:

1) dość częste identyfikowanie dokumentów stricte środowiskowych (np. programu ochrony środowiska) jako dokumentów programujących zrównoważony rozwój gminy. Podejście takie jest charakterystyczne dla przyrodocentrycznego ujmowania zrównoważonego rozwoju, które może być właściwe dla obszarów cennych przyrodniczo, gdzie cele związane z ochroną środowiska będą uznawane za priorytet rozwoju. Dla pozostałych obszarów zalecane jest podejście szersze, zakładające integrację ładu środowiskowego, społecznego i ekonomicznego. Rzadziej taka sytuacja dotyczyła dokumentów społecznych (np. strategii rozwiązywania problemów społecznych);

2) brak pewnych grup celów w triadzie celów społecznych, gospodarczych i środowiskowych lub nieprawidłowe formułowanie celów. Niedoskonałości w tym zakresie dotyczą przede wszystkim nierównowagi w formułowaniu celów. Najczęściej spotyka się sytuację, że wymienionych jest wiele celów gospodarczych, kilka celów społecznych, brakuje natomiast lub wymienionych jest niewiele celów środowiskowych, które dotyczą często obszarów obligatoryjnej aktywności gmin, np. prowadzenia gospodarki odpadami komunalnymi. Innym problemem jest nieprawidłowe lub zbyt ogólne formułowanie celów (np. w formie: cel gospodarczy - wzrost gospodarczy; cel społeczny - dobrobyt społeczny, cel ekologiczny - ochrona środowiska). W niektórych przypadkach na pytanie dotyczące celów odpowiadały samorządy, które wcześniej deklarowały brak dokumentów związanych ze zrównoważonym rozwojem; 
3) braki dotyczące monitoringu. Monitoring postępów w zakresie zrównoważonego rozwoju prowadziło 32,4\% ogółu badanych jednostek (podobne wyniki na poziomie 36\% uzyskano w badaniach prowadzonych w 2010 r. przez Katedrę Zarządzania Ochroną Ś Srodowiska). Uzyskane wyniki wskazują zatem na brak poprawy sytuacji, jeśli chodzi o monitoring, co jest powszechnym problemem występującym w polskich gminach. Monitorowanie oznacza przede wszystkim obserwację zmian w wielu wzajemnie ze sobą powiązanych sferach funkcjonowania danego obszaru (ekonomicznej, społecznej, ekologicznej itp.). Niemożność mierzenia i monitorowania wszystkiego i związane z tym koszty narzucają konieczność stosowania specjalnie do tego celu opracowanej listy wskaźników, jakimi zamierzamy posługiwać się przy ocenie postępów w realizacji idei zrównoważonego rozwoju. Powinny być one określone na etapie opracowania programu zrównoważonego rozwoju, a nie na etapie jego wdrażania. Pozwalają one odpowiedzieć na pytanie: jaki jest stan i jak mierzyć postęp oraz efekty zrównoważonego rozwoju. Zasadniczym zadaniem wskaźników jest wymierne zobrazowanie stopnia realizacji zasad i celów przyjmowanych w programie rozwoju zrównoważonego. Bez prawidłowego określenia listy wskaźników i ich monitorowania nie jest możliwe określenie postępów realizacji programu i wyznaczenie obszarów problemowych, a co za tym idzie - nie jest możliwa korekta realizowanej polityki.

Kolejne kwestie poruszone w badaniu ankietowym dotyczyły barier oraz korzyści z wdrażania zrównoważonego rozwoju w gminie. Badane samorządy uznały za najważniejsze przeszkody we wdrażaniu zrównoważonego rozwoju:

1) ograniczone środki własne gminy, które mogą być przeznaczane na cele związane z ochroną środowiska i zrównoważonym rozwojem. Wskazali tak przedstawiciele $88 \%$ gmin w województwie śląskim. Bariera ta była również wymieniana jako najistotniejsza we wszystkich poprzednich edycjach badań dotyczących wdrażania zrównoważonego rozwoju na poziomie lokalnym, nie zmieniły tego przystą̧pienie Polski do Unii Europejskiej i dostęp do funduszy unijnych;

2) ograniczenia społeczne związane z ugruntowanymi nawykami i zachowaniami mieszkańców (np. spalanie odpadów w piecach) zaznaczone przez przedstawicieli 79\% samorządów. Jednocześnie należy zauważyć, że wiele samorządów nie wykorzystuje dostatecznie instrumentów związanych z edukacją ekologiczną. Kampanie edukacyjno-informacyjne są prowadzone w większości badanych gmin (ok. 74\%), lecz najczęściej ograniczają się do minimum przewidzianego ustawowo, np. obowiązkowej kampanii edukacyjno-informacyjnej prowadzonej przed wprowadzeniem nowego systemu gospodarki odpadami komunalnymi (wymienionej przez większość przedstawicieli samorządów). Drugą formą aktywności edukacyjnej wymienianą przez respondentów jest edukacja ekologiczna w przedszkolach i szkołach. Pozostałe formy edukacji ekologicznej mieszkańców przyjmują takie formy, jak: konkursy ekologiczne, wydawanie broszur informacyjnych oraz 
zamieszczanie informacji o tematyce środowiskowej w internecie i lokalnych gazetach, warsztaty, spotkania i konsultacje z udziałem społeczności lokalnych;

3) ograniczenia prawne i instytucjonalne, z których za najważniejsze uznano niespójność i niejasność przepisów (wskazana przez przedstawicieli $70 \%$ gmin), następnie nadmierną biurokrację i skomplikowane procedury administracyjne w ochronie środowiska (66\%) oraz częste zmiany przepisów (60\%).

Za najmniej ważną przeszkodę ankietowani uznali brak wykształconej kadry w zakresie ochrony środowiska i zrównoważonego rozwoju (9\%). Pozostałe bariery w podziale na pięć grup oraz uszeregowane według liczby wskazań wymieniono w tabeli 2.

Przedstawicieli gmin zapytano również o najważniejsze korzyści wynikające z wdrażania polityki opartej na zasadach zrównoważonego rozwoju. W zakresie korzyści ekonomicznych za najważniejsze uznano: rozwój gospodarczy gminy (64\% wskazań), pozyskanie środków finansowych z funduszy UE (62\% wskazań) oraz poprawę atrakcyjności inwestycyjnej gminy (59\% wskazań). Za najmniej istotne ankietowani uznali: ograniczenie bezrobocia i tworzenie nowych miejsc pracy oraz zwiększenie innowacyjności w gminie (po 32\% wskazań), następnie zwiększenie przedsiębiorczości (33\% wskazań). Spośród korzyści społecznych za najbardziej istotne uznano: poprawę jakości i warunków życia mieszkańców (83\% wskazań), poprawę świadomości ekologicznej mieszkańców (63\% wskazań), zwiększenie dostępności i jakości usług w sferze kultury, sportu i rekreacji, ochrony zdrowia (52\% wskazań). Za mniej ważną kwestię uznano integrację wspólnot lokalnych (23\% wskazań). Najistotniejsze korzyści środowiskowe dotyczą: poprawy czystości i jakości powietrza (72\% wskazań), poprawy stanu środowiska naturalnego (65\% wskazań) oraz utrzymania terenów zielonych (55\% wskazań). Mniej istotne czynniki to według ankietowanych: ochrona dziedzictwa przyrodniczego (25\% wskazań), rekultywacja i zagospodarowanie terenów poprzemysłowych (33\% wskazań) oraz zrównoważone wykorzystanie zasobów wodnych i energii oraz osiągnięcie europejskich standardów w zakresie ochrony środowiska (po 36\% wskazań).

Analizując wyniki uzyskane w długim okresie, można wskazać pewne problemy, które nie są eliminowane od wielu lat. Obok kwestii wspomnianych powyżej jednym z najważniejszych problemów jest brak koordynacji różnych aspektów polityki zrównoważonego rozwoju. Wpływ na taki stan rzeczy ma fakt, że w badanych samorządach bardzo rzadko jest jednostka lub osoba (w mniejszych samorządach, w których nie jest uzasadnione istnienie oddzielnego wydziału) odpowiedzialna za działania podejmowane w różnych obszarach aktywności gmin i je koordynująca. Wyspecjalizowany wydział zajmujący się stricte kwestiami zrównoważonego rozwoju istnieje tylko w gminie Wielowieś, natomiast aż w 61 badanych jednostkach $(51,3 \%)$ nie ma żadnej jednostki lub osoby odpo- 
Tabela 2 . Bariery zrównoważonego rozwoju gmin województwa śląskiego według respondentów (\% ważnych odpowiedzi)

\begin{tabular}{|c|c|}
\hline Bariery zrównoważonego rozwoju & $\%$ wskazań \\
\hline \multicolumn{2}{|l|}{ Bariery prawne i polityczne } \\
\hline Niespójność i niejasność przepisów & 70 \\
\hline Częste zmiany przepisów & 60 \\
\hline Luki prawne & 39 \\
\hline \multicolumn{2}{|l|}{ Bariery instytucjonalne i organizacyjne } \\
\hline $\begin{array}{l}\text { Nadmierna biurokracja i skomplikowane procedury administracyjne w ochronie } \\
\text { środowiska }\end{array}$ & 66 \\
\hline Przewlekłość procedur administracyjnych & 57 \\
\hline Spory kompetencyjne $\mathrm{z}$ innymi instytucjami i administracją rządową & 26 \\
\hline $\begin{array}{l}\text { Brak chęci współpracy pomiędzy różnymi instytucjami i jednostkami samorządu } \\
\text { oraz administracją rządową }\end{array}$ & 22 \\
\hline Brak wykształconej kadry w zakresie ochrony środowiska i zrównoważonego rozwoju & 9 \\
\hline \multicolumn{2}{|l|}{ Bariery finansowe i ekonomiczne } \\
\hline $\begin{array}{l}\text { Ograniczone środki własne gminy, które mogą być przeznaczane na cele związane } \\
\text { z ochroną środowiska i zrównoważonym rozwojem }\end{array}$ & 88 \\
\hline $\begin{array}{l}\text { Skomplikowane procedury uzyskiwania i rozliczania środków finansowych } \\
\text { z funduszy UE }\end{array}$ & 58 \\
\hline Brak inwestorów zewnętrznych & 35 \\
\hline Niska innowacyjność lokalnego przemysłu & 19 \\
\hline Brak zakładów pracy & 19 \\
\hline Niski poziom przedsiębiorczości & 14 \\
\hline Wysokie bezrobocie & 13 \\
\hline \multicolumn{2}{|l|}{ Bariery społeczne } \\
\hline Ugruntowane nawyki i zachowania mieszkańców (np. spalanie odpadów w piecach) & 79 \\
\hline $\begin{array}{l}\text { Niska skłonność do ponoszenia obciążeń związanych z ochroną środowiska } \\
\text { przez mieszkańców (np. unikanie opłat za wywóz odpadów) }\end{array}$ & 57 \\
\hline Niski poziom wiedzy i świadomości ekologicznej społeczeństwa & 44 \\
\hline $\begin{array}{l}\text { Brak akceptacji społecznej dla takich inwestycji, jak: spalarnie odpadów, kompo- } \\
\text { stownie, farmy wiatrowe, elektrownie wodne, biogazownie, wytwórnie biopaliw itp. } \\
\text { (syndrom NIMBY) }\end{array}$ & 44 \\
\hline $\begin{array}{l}\text { Zjawisko ubóstwa i wykluczenia z korzystania z niektórych usług środowiskowych } \\
\text { (np. dostawy wody) ze względu na ograniczenia finansowe mieszkańców }\end{array}$ & 17 \\
\hline \multicolumn{2}{|l|}{ Bariery techniczne } \\
\hline Problemy własnościowe uniemożliwiające lokalizację inwestycji & 43 \\
\hline $\begin{array}{l}\text { Problemy z lokalizacją inwestycji powstających w sferze usług ekologicznych } \\
\text { (brak odpowiednich terenów) }\end{array}$ & 39 \\
\hline Rozproszona zabudowa pociągająca za sobą wysokie koszty inwestycji & 39 \\
\hline $\begin{array}{l}\text { Problemy techniczne związane z charakterystyką terenu (np. ukształtowaniem } \\
\text { terenu, stosunkami wodnymi) }\end{array}$ & 26 \\
\hline
\end{tabular}

Źródło: opracowanie własne na podstawie wyników badań ankietowych. 
wiedzialnej za kwestie zrównoważonego rozwoju. Przedstawiciele pozostałych samorządów najczęściej wskazywali trzy grupy jednostek lub osób zajmujących się kwestiami zrównoważonego rozwoju:

1) wydziały (osoby) zajmujące się planowaniem rozwoju, promocją i pozyskaniem funduszy UE (21 gmin, tj. 17,7\%);

2) wydziały (osoby) zajmujące się ochroną środowiska i aspektami technicznymi (14 gmin, tj. 11,8\%). Wskazuje to na wąskie, przyrodocentryczne rozumienie zrównoważonego rozwoju. W grupie tej dominują gminy wiejskie;

3) wszystkie wydziały według kompetencji (12 gmin, tj. 10,1\%).

Prowadzenie skoordynowanej i wieloaspektowej polityki pozwala na optymalizację działań i uniknięcie zbędnych kosztów. Często działania uznawane przez samorządy za mało istotne i finansowane w ostatniej kolejności mogą przynieść wymierne korzyści. Dobrym przykładem jest ochrona i utrzymywanie tzw. usług ekosystemów bezpośrednio na obszarach miejskich i je otaczających. Kondycja miast zależy w dużej mierze od zdrowego środowiska przyrodniczego. Zdrowe ekosystemy stanowią podstawę zrównoważonego rozwoju miast, ponieważ pozytywnie oddziałują na dobrobyt człowieka i działalność gospodarczą. Z punktu widzenia zachowania usług ekosystemów w miastach za kluczowe można uznać następujące priorytety [Szczepanowska 2012, s. 25-49]:

1) ochronę miast przed zanieczyszczeniami i degradacją walorów środowiska, w tym zasobów wodnych;

2) maksymalizację ilości roślinności, co wiąże się zarówno z zachowaniem istniejących terenów zieleni, jak i z powiększeniem areału terenów zieleni i powierzchni lasów, mających istotny wpływ na czystość powietrza i stabilizację klimatu lokalnego;

3) gospodarowanie zasobami naturalnymi z zastosowaniem zasad restytucji przyrodniczej przy starannym rozważaniu korzyści z ich eksploatacji, ocenianiu stopnia zużycia tych zasobów i możliwości ich odtworzenia.

Władze miejskie, chcąc kierować się zasadami zrównoważonego rozwoju obszarów miejskich, powinny brać pod uwagę takie kierunki działań, jak:

1) ochrona obszarów cennych przyrodniczo znajdujących się wokół zwartego obszaru miejskiego. Szczególnie istotne jest właściwe planowanie przestrzenne i niezabudowywanie obszarów mogących pełnić istotne funkcje, np. lasy mogą być tańszą alternatywą dla kosztownych urządzeń oczyszczających wodę, utrzymanie mokradeł i terenów zalewowych w niezmienionym stanie może być bardziej ekonomiczne niż budowa umocnień przeciwpowodziowych;

2) zagospodarowanie wód opadowych w miejscu wystąpienia opadu, wdrażanie zdecentralizowanych systemów zagospodarowania wód deszczowych i roztopowych opartych na miejscowej retencji, infiltracji, oczyszczaniu oraz ponownym wykorzystaniu wód opadowych; szersze wykorzystanie tzw. zielonej infrastruktury; 
3) ochrona zieleni miejskiej, która jest istotnym czynnikiem wpływającym na jakość życia mieszkańców. Istnienie obszarów zielonych ma także wpływ na ceny na rynku nieruchomości i atrakcyjność miasta dla nowych mieszkańców. Degradacja terenów zielonych w mieście wiąże się z pogarszaniem się jakości powietrza, a wraz z tym również jakości życia. Ograniczane są możliwości rekreacji i efektywnej regeneracji organizmu ludzkiego. Jak pokazują badania, parki miejskie mają zdolność neutralizowania ponad 85\% zanieczyszczeń powietrza trafiających na ich obszar (w przypadku drzew przydrożnych jest to 70\%) [Bernatzky 1983, s. 59-76]. Udział powierzchni pokrytej koronami drzew wpływa wyraźnie na średnią temperaturę powierzchniową terenu. Według badań E.G. McPhersona i in. [1997, s. 49-61] drzewa w Chicago usuwają ok. 5500 ton zanieczyszczeń powietrza, a wartość tej usługi jest szacowana na ponad $9 \mathrm{mln}$ dolarów rocznie. Innym przykładem mogą być polskie szacunki poczynione dla mocno zurbanizowanego fragmentu Pragi-Północ (dzielnicy prawobrzeżnej Warszawy). Według przedstawionych obliczeń, które można uznać za wiarygodne, stwierdzono, że wartość 308 drzew przyulicznych wycenionych na obszarze poligonu badawczego wyniosła 2668460 zł, przy średniej wartości jednego drzewa wynoszącej 8663 zł [Szczepanowska 2014].

Niestety większość tego typu działań wciąż jest rzadko podejmowana przez badane samorządy. Przykładowo wycena wartości usług ekosystemów jest prowadzona przez trzy gminy (co paradoksalnie jest wynikiem bardzo dobrym, ponieważ jest to skomplikowane), zmniejszenie zagrożeń związanych z wodami opadowymi (np. rozszczelnianie powierzchni miast) deklaruje 13 gmin, ochronę lub powiększanie obszarów zielonych - 19 gmin, a promowanie rozwoju rodzajów działalności gospodarczej przyjaznych środowisku - 11 gmin. Za pozytywne należy uznać to, że istnieją samorządy zainteresowane realizacją powyższych działań wychodzących poza katalog zadań własnych gminy. Jest to także istotna poprawa w stosunku do badań prowadzonych w latach wcześniejszych. Badane gminy wykazały natomiast dużo większą aktywność w działaniach związanych z promowaniem postaw proekologicznych (79 gmin, tj. 66,4\%), zmianą sposobu ogrzewania na proekologiczny oraz termomodernizacją (projekty takie realizuje 76 gmin, tj. 63,9\%) czy też poprawą efektywności energetycznej (52 gminy, tj. 43,7\%), co można wiązać z podstawowym problemem ekologicznym wskazywanym przez respondentów, jakim jest niska emisja z domów mieszkalnych i związany z nią zły stan powietrza.

\section{Zakończenie}

Skuteczne wdrażanie polityki zrównoważonego rozwoju wymaga wielu działań w każdej niemal sferze aktywności państwa, gospodarki i społeczeństwa. Reformy ustrojowe w Polsce w ciągu ostatnich kilku lat oraz zasady zrówno- 
ważonego rozwoju zwiększyły w istotnym stopniu rolę władz lokalnych. Po 1990 r. są one prawdziwymi gospodarzami lokalnej społeczności i środowiska. Samorządy gminne prowadzą gospodarkę terenami i zapewniają ład przestrzenny, odpowiadają za infrastrukturę oraz wiele usług niezbędnych do harmonijnego funkcjonowania społeczności. W okresie transformacji pojawiły się również przepisy prawne zobowiązujące władze lokalne do opracowania różnego rodzaju dokumentów planistycznych, sporządzanych przez władze z własnej inicjatywy lub obowiązkowo, wyznaczających kierunki rozwoju społeczności lokalnej. Program zrównoważonego rozwoju ma prowadzić do realizacji społecznie pożądanych celów, takich jak: wzrost realnego dochodu, poprawa stanu zdrowotnego i poziomu wykształcenia, uczciwy dostęp do zasobów środowiska przyrodniczego. Przeprowadzona ocena stanu zaawansowania wdrażania polityki zrównoważonego rozwoju w województwie śląskim wskazuje na duże rozbieżności pomiędzy poszczególnymi samorządami gminnymi. Podczas gdy niektóre samorządy mają wieloletnie tradycje w zakresie wdrażania idei zrównoważonego rozwoju, a procesy programowania rozwoju opartego na jego zasadach są w nich mocno zaawansowane, inne wykazują brak zainteresowania i wiedzy w tym zakresie. Do głównych problemów wpływających na mały stopień zaawansowania procesu wdrażania polityki zrównoważonego rozwoju w samorządach terytorialnych województwa śląskiego należą:

- brak koordynacji różnych aspektów polityki zrównoważonego rozwoju; niewątpliwie wpływ na to ma fakt, że bardzo rzadko istnieje jednostka lub osoba odpowiedzialna za działania podejmowane w różnych obszarach aktywności gmin i je koordynująca;

- niedostrzeganie problemu braku dokumentu strategicznego z zakresu zrównoważonego rozwoju przez władze i społeczności lokalne, a także brak jasnej i kompleksowej metodyki ich opracowania;

- niedostateczna wiedza na temat idei zrównoważonego rozwoju i jego zasad;

- brak środków finansowych na realizację programów zrównoważonego rozwoju;

- brak monitorowania postępów wdrażania zrównoważonego rozwoju, który jest dynamicznym procesem zmian, co uniemożliwia optymalizację i korektę prowadzonej polityki.

Pomimo wspomnianych powyżej problemów nie można mówić o fiasku polityki opartej na zasadach zrównoważonego rozwoju. Polskie samorządy podejmują wiele działań w tym zakresie, a czynniki środowiskowe i społeczne są coraz częściej uznawane przez lokalnych polityków za aspekty równie istotne jak rozwój gospodarczy. Reasumując, można stwierdzić, że istnieje postęp we wprowadzaniu zasad zrównoważonego rozwoju do polityki lokalnej, lecz jest on bardzo wolny. Pierwsze badania przeprowadzane w gminach na początku 
transformacji systemowej wskazywały na ok. 5-procentowy udział samorządów próbujących wdrażać politykę zrównoważonego rozwoju w gminie. Obecnie większość polityków lokalnych i kadry urzędniczej rozumie termin „zrównoważony rozwój", a ok. 25\% badanych gmin ma opracowane podstawowe dokumenty w tym zakresie.

\section{Literatura}

Bernatzky A. [1983], The Effects of Trees on Urban Climate [w:] Trees in the 21st Century, Academic Publishers, Berkhamsted.

Borys T. [2002], Ocena realizacji dokumentów z konferencji z Rio. Administracja samorzadowa [w:] Raport KOMPAS Rio+10, czyli społeczna ocena realizacji przez Polske dokumentów przyjętych na konferencji ONZ „Środowisko i Rozwój” w czerwcu 1992 r. w Rio de Janeiro, Instytut na rzecz Ekorozwoju, Warszawa.

Dokumenty końcowe Konferencji Narodów Zjednoczonych „Środowisko i Rozwój” [1998], Instytut Ochrony Środowiska, Warszawa.

Lorek E. [2001], Program zrównoważonego rozwoju jako narzędzie budowy przewagi konkurencyjnej regionu [w:] Konkurencyjność miast i regionów a przedsiębiorczość i przemiany strukturalne, red. A. Klasik, Wydawnictwo Akademii Ekonomicznej w Katowicach, Katowice.

Lorek A. [2003], Rozwój zrównoważony w regionie ślaskim [w:] Polska a Europa. Procesy demograficzne u progu XXI wieku, red. L. Frąckiewicz, Akademia Ekonomiczna w Katowicach, Katowice.

Lorek E., Sobol A. [2012], Local Sustainable Development in Practice of Silesian Municipalities [w:] Sustainable Development: Theory - Practice - Education, eds D. Pienkowski, A. Makarewicz-Marcinkiewicz, J. Wiland-Szymańska, Wydawnictwo Ekonomia i Środowisko, Poznań-Białystok.

McPherson E.G., Nowak D., Heisler G., Grimmond S., Sauch S., Grant R., Rowntree R. [1997], Quantifying Urban Forest Structure, Function and Value: The Chicago Urban Forest Climate Project, „Urban Ecosystems”, vol. 1, nr 1, https://doi.org/ 10.1023/A:1014350822458.

Międzynarodowe prawo środowiska [2009], wybór i wprowadzenie M.M. Kenig-Witkowska, Oficyna Wolters Kluwer, Warszawa.

Ocena programowania zrównoważonego rozwoju w gminach ślaskich [2010], Katedra Zarządzania Ochroną Środowiska, Uniwersytet Ekonomiczny w Katowicach, Katowice (badania statutowe).

Raport o stanie wdrożenia Lokalnej Agendy 21 w gminach południowej Polski [2000], Polski Klub Ekologiczny Koło Miejskie w Gliwicach, Gliwice.

Report of the World Commission on Environment and Development: Our Common Future [1987], http://www.un-documents.net/our-common-future.pdf (data dostępu: 14.10.2016).

Szczepanowska H.B. [2012], Miejsce terenów zieleni w strukturze zintegrowanego projektowania, zarzadzania i oceny ekologicznej inwestycji miejskich, „Człowiek i Środowisko", nr 36(1-2). 
Szczepanowska H.B. [2014], Rola i znaczenie drzew w mieście, usługi ekosystemowe drzew $i$ wycena ich wartości, Instytut Gospodarki Przestrzennej i Mieszkalnictwa, Warszawa, http://www.igpim.pl/wp-content/uploads/2014/05/Rola-i-znaczenie-drzedw-w-miescie.pdf (data dostępu: 29.10.2014).

United Nations Environment Programme. Report of the Governing Council on the Work of Its Third Session, 17 April - 2 May [1975], United Nations, New York, http:// www.unep.org/sgb/prev_docs/75_0304_GC3_Report_K7510025.pdf (data dostępu: 14.10.2016).

Zarzadzanie środowiskiem na poziomie lokalnym $w$ procesie integracji europejskiej [2002], Katedra Zarządzania Ochroną Środowiska, Akademia Ekonomiczna w Katowicach, Katowice (badania statutowe).

Żylicz T. [2004], Ekonomia środowiska zasobów naturalnych, PWE, Warszawa.

\section{The Sustainable Development Policy of Silesian Municipalities}

(Abstract)

After addressing more immediate problems following the self-governance regained in the 1990s after system transformation, local governments in Silesia began to feel the need to map out a comprehensive development strategy. One possibility for constructing a modern development strategy is to implement the concept of sustainable development. Practical implementation of policies based on the principles of sustainable development first requires local authorities to have the "political will" to implement solutions in accordance with this concept. The research done for this article was intended to help assess the progress municipalities in Silesia have made in implementing sustainable development policies. The basic research method used for the article was analysis of the data contained in the questionnaire "The policy of sustainable development". The questionnaire was carried out by the Department of Social and Economic Policy at the University of Economics in Katowice in 2015. The results of the survey are complemented by an analysis of previously conducted surveys. Based on the studies, it can be concluded that progress has been made, if very slowly, in implementing the principles of sustainable development in local politics. The first studies, which were done in municipalities at the beginning of Poland's post-communism transformation, point to approx. 5\% of local governments trying to implement a policy of sustainable development in their communities. The share has risen to approximately $25 \%$ of the municipalities surveyed.

Keywords: sustainable development, policy, municipalities, Silesian voivodeship. 